this, however, is not surprising, since, for many years, the University has had for examiner one of our ablest chemists and a most eloquent teacher. Nevertheless, observe the following questions, in which the italics are mine :-

"Describe by equations as many processes as you know for the preparation of oxygen gas." (1870.)

"Explain by an equation the process of making ammonia, \&c." (1870.)

"Give the nomes and formule of the oxides of nitrogen, \&c." (I870.)

'These few are the worst detected after careful search; but columns of NATURE could be filled at once with the most un. natural questions in all the other subjects. The following, taken at random, will serve as brilliant specimens; to me they are more heart-rending than the answers given by "Examiner," because even the worst of candidates are corrigible, while examiners do not appear to be so.

"Name the Sovereigns who were reigning in England at the close of each century from the ninth to the eighteenth successively." (1870.)

"Give some estimate of the population of England at the death of Charles II., \&c." (1870.)

"Show how the present Royal Family is comected with the House of Tudor, tracing the pedigree to the end of the seven. teenth century." (1869.)

"State the principal rules of English syntax." (1869.)

Moreover, candidates are positively compelled to cram their Latin and Greek translation; the one Greek and the one Latin subject are selected "one year and a half previously," which makes competition of talent against talent so far practically an impossibility ; it is a mere trial of cramming against cramming. And is this portion of the examination of any practical value as proving the efficiency of a candidate? Let the university answer for itself: "Special stress is laid on accuracy in the answers to the questions in Greek and Latin grammar." Comment is useless.

A much lower standard for Latin translation, and no selection one year and a half previously, would ensure a finer and more useful knowledge of a noble language; besides this, a little rational conduct on the part of examiners, and a far more vigorous and effective supervision of the papers by the Committee of the Senate, would enable education to go hand in hand with instruction, and learning to part company with cramming.

Most of us know what school training should be ; it should be such as would enlarge the mind, make it capable of comprehending the great and good, and open up a vista of happiness in early years. Teachers know what school training must be ; it must be such as will satisfy inexorable examiners, many of whom appear to be totally unmindful, not only of what should, but of what can, be taught during an ordinary boy's school life.

To one who regards education as the only means of placing man "a little lower than the angels," the questions given at elementary examinations are more than painful.

University College School

TEM. AUG. ORME

\section{Volcano near Celebes}

THE following note may be perhaps of interest for the readers of NATuRE. March 2.-The Volcano Roeang, near Tagoelanda, the most southern of the Sangi Islands in the North of Celebes, began to make noises. March 5th.-In the evening, at seven o'clock, a frightful eruption took place; three minutes afterwards a large sea-wave reached the shore of Tagoelanda, about one mile distant from Roeang, and destroyed three villages with 416 men. The mountain worked till March 14, with a heavier final eruption. March 30.-I was at the place and ascended the volcano, which is, according to my measurement, about 2,100 feet high. To proceed into the crater was impossible in consequence of the thick damps of sulphur.

The temperature of the soil at the bottom of the mountain near the sea-shore some inches deep was $45^{\circ}$ Réaumur. I brought home a large collection of stones, \&c.; the masses thrown out were principally sulphur, ashes, sand, and mud, besides small and large stones, and even rocks. All details are contained in my diary. I then made a tour round the Sangi Islands, and am about at this moment to visit the isles of Bangka and Limbe in the north and east of North Celebes.

Manado, Celebes, April

\section{NOTES}

Vice-Admiral E. Ommanney, C.B., F.R.S., proceeds to Antwerp to represent the Royal Geographical Society of London at the Congress of Geographical Science, which will be held in that city between the 14 th and 22 nd of this month.

Mr. W. CARruthers has just issued his official report for I 870 of the Botanical Department of the British Museum. Several of the Natural Orders and European and British representatives of other orders have been completely rearranged. The most important additions which have been incorporated into the herbarium during the year are: from Formosa, collected by the late Mr. Oldham; from the Levant, 2,625 species by Prof. Haulssknecht : from Martinique, by M. Hahn; and from various districts of Europe. A large number of fungi have been added from Europe, and from North and South America and Cuba, and among other palæozoic additions, an important series of Devonian plants from Canada, presented by Principal Dawson, of Montreal, illustrating his published memoirs.

THE Monthly and Annual Reports have reached us of the Department of Agriculture of the United States of America for 1868 and 1869. The amount of information which is thus afforded by the Government to the citizens of the United States, may well astonish us in this country. They comprise Reports from practical men on a vast variety of subjects of the utmost imporlance to the cultivators of the soil: the cultivation of fruit; the mantres best adapted for different soils; report of recent progress in steam culture; meteorological statistics; the physiology of Trichina spiralis; abstract of laws relating to fences and wild stock; tests for the authenticity of seeds; agricultural statistics; report of progress of beet-sugar manufacture in Europe, et multa alia.

THE discussion which took place before Parliament relating to the adoption of the metric system in England, is considered by French savans as highly discreditable to that body, and the result has occrsioned much surprise there.

M. BRETON, one of the great Hachette firm, was returned a member of the Municipal Council of Paris in the Conservative interest. His majority was one vote, which was declared nil, as a man had vcted without any right, and in spite of the exertions of the chairman of his voting section. Being older than $M$. Hérisson, his competitor, he was elected merely by the privilege of seniority. Two other publishers who had been candidates were unsuccessful, M. Gernier Baillière and M. Victor Masson.

No stamp duty is to be imposed on newspapers in France, but a duty will be established on every description of printing-paper. For books it will $8 s$. per cwt. and for newspapers $16 s$. per cwt. Newspaper paper is of an inferior description, and will be charged twice as much as the superior kind. This absurdity is owing to the objection raised to the income-tax by several politicians, amongst them M. Thiers himself. But it is supposed he will very shortly give up his old prejudices.

Mr. Carruthers, the keeper of the herbarimm at the British Museum, has been appointed consulting botanist to the Royal Agricultural Society.

ONE of the Whitworth Scholarships has recently been awarded to John Armitage, an artizan student at the Oldham School of Science and Art; last year he gained the Department Silver Medal for Practical Geometry, and in 1869 the silver medal for Machine Drawing. Last year James Taylor, another artizan student from this school, aIso gained a Whitworth Scholarship, as well as the Department Gold Medal for Mathematics and the silver medal for Theoretical Mechanics.

A LAUDABLE attempt to encourage floriculture in London is an exhibition which was held yesterday in the churchyard of St. 